\title{
Preliminary study on temporal variations in biting activity of Simulium damnosum s.I. in Abeokuta North LGA, Ogun State Nigeria
}

\author{
Akinola S Oluwole ${ }^{1}$, Uwem F Ekpo*1, Chiedu F Mafiana², \\ Clement O Adeofun ${ }^{3}$ and Olufunmilayo A Idowu ${ }^{1}$
}

\begin{abstract}
Address: ${ }^{1}$ Department of Biological Sciences, University of Agriculture, Abeokuta, Nigeria, ${ }^{2}$ Academic Planning Unit, National Universities Commission, Abuja, Nigeria and ${ }^{3}$ Department of Environmental Management and Toxicology, University of Agriculture, Abeokuta, Nigeria

Email: Akinola S Oluwole - agapeolu@yahoo.com; Uwem F Ekpo* - ufekpo@hotmail.com; Chiedu F Mafiana - chiedu.mafiana@gmail.com; Clement O Adeofun - clemluv2000@yahoo.com; Olufunmilayo A Idowu - tomiwo2@gmail.com

* Corresponding author
\end{abstract}

Published: 16 November 2009

Parasites \& Vectors 2009, 2:55 doi:10.1186/1756-3305-2-55
Received: I September 2009

Accepted: 16 November 2009

This article is available from: http://www.parasitesandvectors.com/content/2/1/55

(C) 2009 Oluwole et al; licensee BioMed Central Ltd.

This is an Open Access article distributed under the terms of the Creative Commons Attribution License (http://creativecommons.org/licenses/by/2.0), which permits unrestricted use, distribution, and reproduction in any medium, provided the original work is properly cited.

\begin{abstract}
Background: Simulum damnosum Theobald sensu lato (s.l.) is the vector of the parasitic filarial worm Onchocerca volvulus Leuckart which causes onchocerciasis. In order to understand the vector population dynamics, a preliminary 12 months entomological evaluation was carried out at Abeokuta, the Southwest Zone of Nigeria, an onchocerciasis endemic area, where vector control has not been previously initiated. S.damnosum s.l. flies were caught on human attractants between 700 to 1800 hours each day, for 4 days each month, from August 2007 to July 2008. The flies caught were classified as either forest-dwelling or savanna-dwelling groups based on the colour of certain morphological characters. Climatic data such as rainfall, humidity and temperature were also collected monthly during the period of survey.
\end{abstract}

Results: A total of I, I 39 flies were caught, 596 (52.33\%) were forest-dwelling group while 543 (47.67\%) were savannadwelling group of $S$. damnosum s.l. The highest percentage of forest-dwelling group was caught in the month of August 2007 (78.06\%) and the least percentage of forest-dwelling groups was caught in November 2007 (8.14\%). The highest percentage of savannah-dwelling group was caught in the month of November 2007 (91.86\%) and the least percentage of savannah-dwelling group was caught in August 2007 (21.94\%). There was no significant difference between the population of forest and savannah-dwelling groups of the fly when the means of the fly population were compared $(P=$ 0.830). Spearman correlation analysis showed a significant relationship between monthly fly population with monthly average rainfall $(r=0.550, n=12, P=0.033)$, but no significant relationship with monthly average temperature $(r=0.291$, $n=12, P=0.179)$. There was also a significant relationship between monthly fly population and monthly average relative humidity $(r=0.783, n=12 P=0.001)$. There was no significant correlation between the population of forest-dwelling group of $S$. damnosum s.l. and monthly average rainfall $(r=0.466, n=12, P=0.064)$ and monthly average temperature $(r$ $=0.375, \mathrm{n}=12, P=0.115)$ but there was significant correlation with monthly average relative humidity $(r=0.69, n=12$, $P=0.006)$. There was significant correlation between savannah-dwelling group and monthly average rainfall $(r=0.547, n$ $=12, P=0.033)$, and monthly average relative humidity $(r=0.504, n=12, P=0.047)$ but there was no significant correlation with monthly average temperature $(r=0.142, n=12, P=0.329)$

Conclusion: The results from this study showed that both the forest and the savannah dwelling groups of $S$. damnosum s.l. were caught biting in the study area. This could have implications on the transmission and epidemiology of human onchocerciasis if not monitored. 


\section{Background}

The Simulium damnosum Theobald complex are the only vectors of Onchocerca volvulus Leuckart, filarial parasite causing the human onchocerciasis in West Africa [1]. Onchocerciasis disease may be mild (dermatitis) or severe (visual impairment and blindness) and is caused by the human immune response to microfilaria released by female adult worms as they move across subcutaneous tissue and spread throughout the body. Humans are the only known reservoir [2]. The prevalence of human onchocerciasis has been observed to be directly related to the presence and abundance of its vector, $S$. damnosum sensu lato (s.l.) [3]. Early findings have shown that there were geographical variations among West African populations of $S$. damnosum s.l. and that these were related to savannah and forest environment [4-6]. Several studies have shown that the savannah-dwelling vectors of onchocerciasis transmit the blinding form of onchocerciasis while the forest-dwelling vectors transmit the non blinding form of the disease known as onchodermiatiasis $[7,8]$. Therefore, a reliable identification of biting adult females of $S$. damnosum s.l that transmit the forest and savannah strains of Onchocerca volvulus has being considered very essential in the study of transmission and epidemiology of human onchocerciasis [9]. In addition, a detailed understanding of parasite and vector population dynamics is crucial for vector control in the future [1012]. In Abeokuta, Nigeria, control of onchocerciasis is based on annual mass treatment with Ivemectin (Mecti$\mathrm{zan}^{\circledR}$ ) drug, a microfilaricide, as there is no vector control. Therefore, the present work is aimed at identifying $S$. damnosum s.l sibling species biting at Iwofin River in order to provide data on the vector in Abeokuta southwestern zone of Nigeria, which can be useful for vector control of this disease in the future.

\section{Results}

\section{Population of S. damnosum s.I}

Out of 1,139 flies caught at Iwofin River, 596 (52.33\%) were identified as forest-dwelling group while 543 $(47.67 \%)$ were identified as savannah-dwelling group. There was no significant difference between the population of the forest and savannah groups caught when there means was compared $(P=0.830)$. Table 1 shows monthly variation of $S$. damnosum s.l. population with average temperature, relative humidity and average rainfall during the period of study. The populations of the forest-dwelling group were higher than those of the savannah-dwelling group of S. damnosum s.l. from August 2007 to September 2007, but from October 2007 till June 2008, population of the savanna strains was higher than that of the forest flies. In July 2008, population of forest-dwelling group increased beyond that of the savannah-dwelling group. The highest percentage of forest-dwelling group of $S$. damnosum s.l flies was caught in the month of August 2007
(78.06\%) and the least percentage of forest-dwelling groups of $S$. damnosum s.l. flies was caught in November 2007 (8.14\%). The highest percentage of savannah-dwelling group of $S$. damnosum s.l. flies was caught in the month of November 2007 (91.86\%) and the least percentage of savannah-dwelling groups of S. damnosum s.l. flies was caught in August 2007 (21.94\%). Figure 1 shows the hourly biting rate of $S$. damnosum in the study area.

\section{Relationship between meteorological data and fly population}

The relationship between monthly average rainfall, average temperature, average relative humidity and fly population using spearman non parametric correlation analysis showed that there were significant relationship between average rainfall and fly population $(r=0.550, \mathrm{n}$ $=12, P=0.033)$ and average relative humidity and fly population $(r=0.783, n=12 P=0.001)$ but no significant relationship between average temperature and fly population $(r=0.291, n=12, P=0.179)$. Also there was no significant relationship between forest-dwelling group of $S$. damnosum s.l. with average rainfall $(r=0.466, n=12, P=$ $0.064)$ and average temperature $(r=0.375, \mathrm{n}=12, P=$ $0.115)$ but there was significant relationship with relative humidity $(r=0.69, n=12, P=0.006)$. However, there was significant relationship between savannah-dwelling group and monthly average rainfall $(r=0.547, n=12, P=$ $0.033)$, and monthly average relative humidity $(r=0.504$, $n=12, P=0.047)$ but there was no significant correlation with monthly average temperature $(r=0.142, n=12, P=$ $0.329)$.

\section{Discussion}

The epidemiology of onchocerciasis is determined by multiple factors such as vector ecology, parasite biology, host immunology, and social factors. The variation in the pathology of onchocerciasis disease from one ecological zone to another has been attributed to the different sibling's species of $S$. damnosum s.l transmitting different strains of Onchocerca volvulus Leuckart. Thus S. damnosum s.l. has been divided into forest-dwelling and savannahdwelling group $[13,14]$. Savannah-dwelling group of $S$. damnosum s.l. are usually found in savanna zone and the forest dwelling group of S. damnosum s.l. are usually confined to the forest zone [13]. In view of this, it is expected that only the forest-dwelling group of $S$. damnosum s.l. will be found in the study area since it is located in the forest zone of Nigeria. The presence of the savannah-dwelling group of $S$. damnosum s.l.in this region could be due to the migration of the savannah-dwelling group of $S$. damnosum s.l. flies into the study area from Northern part of Nigeria which is savannah. This may be due to massive deforestation in the study area, for farming, logging and other agricultural activities [15]. Some studies have reported the impact of deforestation on the abundance and distribu- 
Table I: Relative abundance of forest and savannah dwelling groups of S. damnosum s.l. caught biting at Abeokuta, southwestern Nigeria from August 2007 to July 2008

\begin{tabular}{|c|c|c|c|c|c|c|}
\hline Months & $\begin{array}{c}\text { Number of flies of } \\
\text { savannah dwelling } \\
\text { group }\end{array}$ & $\begin{array}{c}\text { Number of flies } \\
\text { forest dwelling } \\
\text { group }\end{array}$ & $\begin{array}{l}\text { Monthly } \\
\text { Total flies }\end{array}$ & $\begin{array}{c}\text { Monthly Average } \\
\text { Temperature } \\
\left({ }^{\circ} \mathrm{C}\right)\end{array}$ & $\begin{array}{c}\text { Monthly Average } \\
\text { Rainfall } \\
(\mathbf{m m})\end{array}$ & $\begin{array}{c}\text { Monthly Average } \\
\text { Relative Humidity } \\
\text { (\%) }\end{array}$ \\
\hline $\begin{array}{l}\text { August } \\
2007\end{array}$ & 52 & 185 & 237 & 31.5 & 32.3 & 78.9 \\
\hline September 2007 & 28 & 90 & 119 & 28.6 & 16.1 & 81.5 \\
\hline $\begin{array}{l}\text { October } \\
2007\end{array}$ & 96 & 45 & $|4|$ & 26.2 & 25.0 & 76 \\
\hline November 2007 & 79 & 7 & 86 & 26.7 & 18.5 & 65.9 \\
\hline December 2007 & 46 & 11 & 57 & 25.8 & 16.4 & 69.2 \\
\hline $\begin{array}{l}\text { January } \\
2008\end{array}$ & 6 & 3 & 9 & 24.9 & 0 & 58.4 \\
\hline February 2008 & 15 & 22 & 37 & 26.1 & 0 & 64.1 \\
\hline $\begin{array}{l}\text { March } \\
2008\end{array}$ & 89 & 25 & 114 & 26.9 & 24.3 & 64.2 \\
\hline $\begin{array}{l}\text { April } \\
2008\end{array}$ & 24 & 11 & 35 & 27.3 & 30.7 & 63.6 \\
\hline $\begin{array}{l}\text { May } \\
2008\end{array}$ & 28 & 12 & 40 & 27.3 & 13.8 & 62.6 \\
\hline $\begin{array}{l}\text { June } \\
2008\end{array}$ & 17 & 11 & 28 & 26.7 & 23.4 & 68.8 \\
\hline $\begin{array}{l}\text { July } \\
2008\end{array}$ & 62 & 174 & 236 & 25.6 & 28.2 & 73.2 \\
\hline Total/Average & 543 & 596 & 1139 & 26.9 & 19.1 & 68.9 \\
\hline
\end{tabular}

tion of vectors of diseases $[16,17]$. The implication of the presence of the savannah-dwelling group of $S$. damnosum s.l. is the possible transmission of the blinding form of onchocerciasis which is associated with savannah-dwelling group [18]. Although there was no significant difference in the population of the two groups, it is however important that the population dynamic of $S$. damnosum s.l in this area be monitored continuously for possible establishment and breeding of savannah dwelling group. Therefore the prospecting and identification of larva stages of $S$. damnosum s.l. using cytotaxonomic methods is urgently needed to truly establish the breeding of savannah dwelling group [19]. The establishment of savannah dwelling group in the area will consequently result in changes in transmission, epidemiology and the pathology of the disease [20].
The relationship between monthly rainfall and population of flies caught at Abeokuta, southwest zone of Nigeria was not significant at 0.001 levels; thus increase in rainfall does not necessary result in increase in S. damnosum s.l. population. Also the biting rate of $S$. damnosum s.l. flies caught at the study area shows three peak of biting activity and not the usual two peaks reported by many authors on biting activity of $S$. damnosum s.l. These observations differs from the findings of other investigators in the other forest zones of Nigeria where an increase in rainfall significantly affects fly population and show a diurnal biting rate for $S$. damnosum [21-23]. This could possibly be due to climatic changes in the study area as a result deforestation, and possibly global warming. The decline in S. damnosum s.l. abundance in the months of April and May 2008 could be due to washing away of the larval stages in Iwofin River as consequence of flooding [23]. 


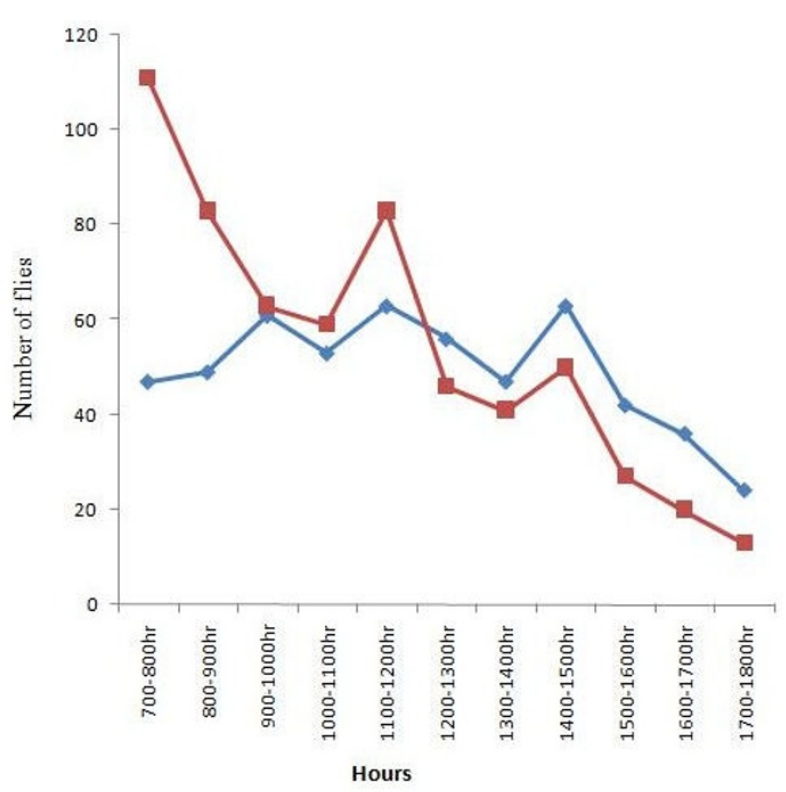

Figure I

Biting trend of S. damnosum s.l. at Iwofin River, Abeokuta, Southwestern Nigeria. The red line in the graph represents the biting trend of forest dwelling group, while the blue line represents the biting trend of savannah dwelling group respectively.

More flies were caught in the rainy season (August 2007) than in the dry season (November 2007 to February 2008). This may have resulted from the stimulus of increased oxygen content of the water during rainy season which causes fly to emerge from pupae coupled with increased amounts of nutrients and availability of preimaginal sites, all of which enhance pre-imaginal development of $S$. damnosum s.l., which then results in an increase in the adult fly population during the rainy season [24]. The rainy season has been reported to be accompanied by flooding and phytoplankton (detritus, bacteria, diatoms and filamentous algae) blooms [25]. This phytoplankton is the food required by Simulium larvae for its development [22]. However, the higher population of savannah-dwelling group of $S$. damnosum s.l. caught during the dry season support the hypothesis that the savannah-dwelling group of $S$. damnosum s.l. flies migrate southward during the dry season in search of breeding sites and blood meal [22]. The strong positive correlation observed between relative humidity and fly abundance is due to the influence of humidity on biting activity of $S$. damnosum s.l. This is similar to other studies where increase in biting activity of $S$. damnosum s.l. is related to increase in relative humidity $[26,27]$.

\section{Conclusion}

The finding from this study shows that, both the forest and savannah dwelling groups of $S$. damnosum s.l. were caught biting in the study area. There is therefore a need for systematic monitoring of the population of $S$. damnosum s.l. in order to establish a possible invasion and breeding of savannah-dwelling group of $S$. damnosum s.l.in this area. Early warning of changes in species composition of S. damnosum s.l. is very important in the detection of any trend of change in transmission and epidemiology of onchocerciasis.

\section{Materials and methods Study area}

The study was carried out at Iwofin River $\left(7.24936^{\circ} \mathrm{N}\right.$, $3.23321^{\circ} \mathrm{E}$ ). Iwofin River is a fast flowing river that begins at Iwofin and empties into Oyan River. It is a breeding site of $S$. damnosum s.l in Abeokuta North Local Government Area of Ogun State located in the southwest zone of Nigeria. The region lies between altitudes $59 \mathrm{~m}-62 \mathrm{~m}$. The area is situated in the forest zone of Nigeria. However, the vegetation is that of a derived savannah, consisting of many grasses and few trees due to local deforestation such as land cultivation, pastoral farming and logging.

\section{Entomological methods}

Adult female of $S$. damnosum s.l. flies were caught on human attractants. Two human attractants were stationed alternatively for one hour from 0700 and 1800 hour at a location few meters from the breeding site of $S$. damnosum s.l. on Iwofin River. The Human attractants sat on a bench with their legs exposed. Any fly perching on the exposed parts was caught before it fed by inverting a small glass tube over it. The caps of the tube were then immediately replaced. All tubes containing flies were labeled to indicate time of capture. Each fly was caught with a separate tube. Collections were made on two consecutive days at every fortnight making a total of four days of collection every month from July 2007 to August 2008.

\section{Identification of S. damnosum s.l. using morphological characters}

Adult females of $S$. damnosum s.l. flies caught were identified immediately on the field with the aid of field microscope using taxonomic keys [28] that focused on the colour of morphological characters which include wingtuft, forecoxa, arculus, antennae, $9^{\text {th }}$ abdominal segment setae and scutella setae. The flies were classified as a member of either the forest-dwelling group or savannahdwelling group. A $S$. damnosum s.l. with a pale colour for all the morphological characters mentioned above is classified as a member of the savannah-dwelling group while a fly with a dark colour for any or all of the morphological characters is classified as a forest fly [28]. Flies that were not identified in the field due to poor visibility were pre- 
served in cotton wool soaked in fresh water and transported to the laboratory where they were later identified as described above.

\section{Climatological data}

Monthly average temperature, monthly average rainfall and monthly average relative humidity of the study area were collected to determine its influence on population dynamics of $S$. damnosum s.l. The data were collected every month from the Hydrology department of the OgunOsun River Basin Development Authority, Abeokuta.

\section{Competing interests}

The authors declare that they have no competing interests.

\section{Authors' contributions}

EUF and OAS initiated the study, EUF and OAS designed the study. OAS collected the data and EUF, MCF, ACO and IOA supervised the data collection. OAS and EUF did the data analysis and interpretation; OAS and EUF wrote the manuscript. OAS, EUF, MCF, IOA and ACO reviewed the manuscript.

\section{Ethical Approval}

Approval for the study was obtained from the Ogun State Ministry of health and individuals used as human attractant were informed of the consequences of S. damnosum s.l. bite and were treated with ivermectin before and after the study.

\section{Acknowledgements}

The authors wish to thank Ogun State Ministry of Heath, Mr. Victor Osikoya, the State Onchocerciasis Control Programme Manager, Mr. Aliyu,

Local Onchocerciasis Programme Manager of Abeokuta North Local Government Area, for their logistic support. We thank the human attractants and the entire member of Ibaro community for their cooperation during the study.

\section{References}

I. Ibeh OO, Nwoke BEB, Adegoke JA, Mafuyai HB: Cytospecies identifications of vectors of human onchocerciasis in south eastern Nigeria. Afr J Biotechnol 2006, 5:1813-1818.

2. Gonzalez RJ, Cruz-Ortiz N, Rizzo N, Richards J, Zea-Flores G, Domínguez A, Sauerbrey M, Catú E, Oliva O, Richards FO Jr, Lindblade KA: Successful Interruption of Transmission of Onchocerca volvulus in the Escuintla-Guatemala Focus, Guatemala. PLoS Negl Trop Dis 2009, 3(3): e404. doi:I0.137//journal.pntd.0000404

3. Crosskey RW: A review of Simulium damnosum s.l. and human onchocerciasis in Nigeria, with special reference to the geographical distribution and the development of Nigeria national control campaign. Tropenmedizin und Parasitologie |99।, 32:2-16.

4. Duke BOL, Lewis DJ, Moore PJ: Onchocerca-Simulium complexes V. Transmission of forest and savannah strains of Onchocerca from Cameroun by Simulium damnosum from various West Africa bioclimate. Ann Trop Med Parasitol 1966, 60:318-336.

5. Duke BOL, Moore PJ: The contribution of different age groups to the transmission of Onchocerciasis in a Cameroon forest village. Trans $R$ Soc Trop Med Hyg 1968, 62:22-28.

6. Duke BOL: Studies on factors influencing the transmission of Onchocerciasis VI: The infective biting potential of Simulium damnosum in different bioclimatic zones and its influence on the transmission potential. Ann Trop Med Parasitol 1967, 62:164-170.

7. Zimmerman PA, Dadzie KY, De sole G, Remme J, Soumbey AE, Unnasch TR: Onchocerca volvulus DNA probe classification correlates with epidemiological patterns of blindness. J Infect Dis 1992, 165:964-968.

8. Yaméogo L, Resh VH, Molyneux DH: Control of River Blindness in West Africa: Case History of Biodiversity in a Disease Control Program. Ecohealth 2004, I(2): I72-I83.

9. Ibeh OO, Nwoke BEB, Adegoke JA: Morphological differentiation of vectors of Onchocerciasis, Simulium damnosum complex, in south-east Nigeria. Nigeria J Parasitol 2008, 29(I):6|-66.

10. Tibayrenc $M$ : Towards an integrated genetic epidemiology of parasitic protozoa and other pathogens. Annu Rev Genet 1999, 33:449-477.

II. De Meeus T, McCoy KD, Prugnolle F, Chevillon C, Durand P: Population genetics and molecular epidemiology or how to "debusquer la bete". Infect Genet Evol 2007, 7:308-332.

12. Solano P, Ravel S, Bouyer J, Camara M, Kagbadouno MS, Dyer N, Gardes L, Herault D, Donnelly MJ, Meeus TD: The Population Structure of Glossina palpalis gambiensis from Island and Continental Locations in Coastal Guinea. PLoS Negl Trop Dis 2009, 3(3):e392 doi:10.1371/journal pntd 0000392

13. Onchocerciasis and its control. In Report of a WHO Expert Committee on onchocerciasis control. WHO Technical Report Series, No. 852 World Health Organization, Geneva; 1995.

14. Opoku AA: Ecology and Biting Activity of Blackflies (Simuliidae) and the Prevalence of Onchocerciasis in an Agricultural Community in Ghana. West Afr J appl Ecol 2006, 9: I-7.

15. Ecosystems and Human Wellbeing: Synthesis Report Island Press, Washington (DC); 2005.

16. Yasuoka J, Levins R: Impact of deforestation and agricultural development on anopheline ecology and malaria epidemiology. Am J Trop Med Hyg 2007, 76:450-460.

17. O'Sullivan L, Jardine A, Cook A, Weinstein P: Deforestation, Mosquitoes, and Ancient Rome: Lessons for Today. BioScience 2008, 58(8):756-760.

18. Duke BOL: Geographical aspects of onchocerciasis. Annals de la Societe Belge de Medicine Tropical 198I, 61:179-|86.

19. Bissan Y, Hougard JM, Doucouré K, Akpoboua A, Back C, Poudiougo P, Sib AP, Coulibaly Y, Guillet P, Sessay I, Quillévéré D: Drastic reduction of populations of Simulium sirbanum (Diptera: Simuliidae) in central Sierra Leone after 5 years of larviciding operations by the Onchocerciasis Control Programme. Ann Trop Med Parasitol 1994, 89(suppl I):63-72.

20. Trpis $M$ : Consequences of vector behavior in epidemiology of onchocerciasis on the firestone rubber plantation in Liberia. Am J Trop Med Hyg 2006, 74:833-840.

21. Crosskey RW: Observations of the bionomics of adult Simulium damnosum (Theobald) (Dipthera Simulidae) in northern Nigeria. Ann Trop Med Parasitol 1955, 49: I 42-153.

22. Crosskey RW: The Natural History of Blackflies British Museum (Natural History), London: John Wiley and Sons; 1990.

23. Opara KN, Olakunle B, Fagbemi BO, Asuquo E, Okenu DMN: Status of forest onchocerciasis in the Lower Cross river basin, Nigeria: Entomologic profile after five years of ivermectin treatment. Am J Trop Med Hyg 2005, 73(2):37I-376.

24. Opara KN, L P, Usip LP, Akpabio EE: Transmission dynamics of Simulium damnosum in rural communities of Akwa Ibom State, Nigeria. J Vector Borne Dis 2008, 45:225-230.

25. Adebisi AA: The physico-chemical hydrology of a tropical seasonal river, Upper Ogun River. Hydrobiologia 198I, 79:157-165.

26. Crosskey RW: A review of Simulium damnosum s.l. and human onchocerciasis in Nigeria, with special reference to the geographical distribution and the development of Nigeria national control campaign. Tropenmedizin and Parasitologie 1981, 32:2-16.

27. Lancey LA, Charlwood JD: On the biting activities of some anthropophilic Amazonian Simuliidae (Diptera). Bull Entomol Res 1981, 70(3):495-509.

28. Wilson MD, Mafuyai HB, Post RJ: Morphological identification of Sibling species of the Simulium damnosum (Diptera:Simuliidae) complex from Nigeria, Cameroon and Bioko. Proceedings of the Section of Experimental and Applied Entomology of the Netherlands Entomological Society. N.E.V.Amsterdam I994, 5:|8|-| 85. 